\title{
Barriers and Facilitators to Fertility-Related Discussions with Teenagers and Young Adults with Cancer: Nurses' Experiences
}

\author{
Wendy Norton, PhD, MSc, BSc, and Elaine Wright, MSc
}

Introduction: Improvements in cancer survival rates for teenagers and young adults (TYAs) have resulted in quality-of-life issues into survivorship becoming increasingly important. However, infertility is a potential late side effect of cancer treatment, which can negatively impact on quality of life. Advances in assisted reproductive technologies have resulted in increasingly effective fertility preservation (FP) options.

Purpose: This study aimed to explore nurses' experiences of undertaking fertility-related discussions with TYAs with cancer aged 13-24 years.

Methods: An interpretive phenomenological analysis (IPA) approach was used. Eleven purposively selected nurses working on a specialist TYA cancer unit participated in semistructured interviews. Data were analyzed using IPA. Results: Parents/family were experienced as self-appointed informal gatekeepers who were perceived to hold the power to control nurses' access to communicate with young people about fertility issues. Nurses adopted a supportive role, which was enhanced by the positive nature of their relationship with the TYA. Uncertainty was expressed over whether the TYA had been fully informed of their infertility risk and potential FP options.

Conclusions: Nurses should manage parental involvement sensitively if TYAs are to make informed decisions regarding their future reproductive health. There is a need for clear role delineation in fertility discussions to ensure that TYAs are provided with the opportunity to discuss infertility risk and be referred to a specialist before initiating cancer treatment. Nurses should cultivate the primacy of the nurse-TYA relationship to improve fertility care. Further research into the factors that TYAs may consider beneficial within the nursepatient relationship is required.

Keywords: nurse, cancer, teenager, young adult, fertility preservation/discussion

\section{Introduction}

I MPROVEMENTS IN CANCER Survival rates for teenagers and young adults (TYAs) ${ }^{1}$ have resulted in quality-of-life issues such as infertility becoming increasingly important. Infertility is a sequela of cancer treatment, but determining individual risk is challenging. ${ }^{2}$ While some cancer treatments are unlikely to compromise fertility, it is difficult to predict the likelihood of relapse requiring second-line therapy that is likely to cause infertility. ${ }^{3}$

Advances in assisted reproductive technologies have resulted in increasingly effective fertility preservation (FP) options for those of reproductive age ${ }^{3,4}$ (Table 1, FP options). International clinical guidance recognizes the importance of FP for TYAs with cancer and states that discussion of potential infertility risks and FP options/referral before treatment is essential. ${ }^{5-11}$ The ability to retain reproductive potential is of primary concern for TYAs, both nationally and internationally. ${ }^{12-16}$ Yet, TYAs often experience inadequate fertility information provision, which may be a source of significant dissatisfaction. ${ }^{17-26}$

TYAs report clear preferences for fertility-related discussion, including a respectful, open, and honest approach, ${ }^{19,27}$ recognition of the importance of fertility, ${ }^{23}$ and improved communication between oncologists and fertility specialists. ${ }^{28}$ In addition, TYAs strongly desire a participatory decisionmaking role. ${ }^{29-32}$ As research consistently indicates that receiving information about the impact of cancer on fertility is associated with lower patient distress, ${ }^{19}$ improved quality of life, ${ }^{10,20,26}$ less regret, ${ }^{33,34}$ and improved coping, ${ }^{15}$ it is critically important to engage in timely discussions to maximize future FP opportunities.

Despite guideline recommendations, barriers exist which may impede FP discussion. In the limited studies using a nurseonly sample, research from the United States, Netherlands, and Canada demonstrates that a lack of knowledge and training on

Faculty of Health and Life Sciences, The Leicester School of Nursing and Midwifery, De Montfort University, Leicester, United Kingdom. 
Table 1. Fertility Preservation Options

\begin{tabular}{|c|c|c|c|c|}
\hline & Fertility options & $\begin{array}{c}\text { Clinical } \\
\text { considerations }\end{array}$ & Advantages & Disadvantages \\
\hline \multirow[t]{6}{*}{$\begin{array}{l}\text { Young } \\
\text { males }\end{array}$} & $\begin{array}{l}\text { Cryopreservation of } \\
\text { spermatozoa }\end{array}$ & $\begin{array}{l}\text { Standard technique } \\
\text { Postpubertal males }\end{array}$ & $\begin{array}{l}\text { Achievable in males as } \\
\text { young as } 11 \text { years }\end{array}$ & Postpubertal males only \\
\hline & Frozen in liquid nitrogen & & No pre-treatment required & \\
\hline & $\begin{array}{l}\text { Sample of semen obtained } \\
\text { by masturbation }\end{array}$ & & Proven efficacy & \\
\hline & $\begin{array}{l}\text { Electro-ejaculation under } \\
\text { anesthesia }\end{array}$ & & & \\
\hline & Testicular tissue & Prepubertal males & No pre-treatment required & Requires surgical \\
\hline & $\begin{array}{l}\text { cryopreservation } \\
\text { Surgical removal of tissue } \\
\text { preserved for later } \\
\text { transplantation in } \\
\text { adulthood }\end{array}$ & Experimental & $\begin{array}{l}\text { Anesthesia risk minimized if } \\
\text { surgery was performed at } \\
\text { the time of another element } \\
\text { of treatment requiring } \\
\text { general anaesthesia }\end{array}$ & $\begin{array}{l}\text { procedure under } \\
\text { anesthesia }\end{array}$ \\
\hline \multirow{7}{*}{$\begin{array}{l}\text { Young } \\
\text { females }\end{array}$} & Embryo cryopreservation & Postpubertal females & Established option & \multirow[b]{2}{*}{$\begin{array}{l}\text { Requires ovarian } \\
\text { stimulation before } \\
\text { treatment resulting in } \\
\text { delay of } 2-3 \text { weeks } \\
\text { Requires male partner or } \\
\text { donor sperm }\end{array}$} \\
\hline & $\begin{array}{l}\text { Transvaginal removal of } \\
\text { eggs }\end{array}$ & Single females & Proven efficiency & \\
\hline & Oocyte preservation & \multirow[t]{3}{*}{ Postpubertal females } & Suitable for females with & \multirow{3}{*}{$\begin{array}{l}\text { Decreased efficacy } \\
\text { compared to embryo } \\
\text { cryopreservation }\end{array}$} \\
\hline & $\begin{array}{l}\text { Eggs are thawed and } \\
\text { fertilized with sperm to } \\
\text { create embryos }\end{array}$ & & $\begin{array}{l}\text { ethical or religious } \\
\text { objection to embryo } \\
\text { preservation }\end{array}$ & \\
\hline & & & No need for male partner & \\
\hline & $\begin{array}{l}\text { Ovarian tissue } \\
\text { cryopreservation }\end{array}$ & $\begin{array}{l}\text { Prepubertal females } \\
\text { Postpubertal females }\end{array}$ & $\begin{array}{l}\text { Does not require sexual } \\
\text { maturity }\end{array}$ & \multirow{2}{*}{$\begin{array}{l}\text { Potential for tissue to be } \\
\text { seeded with malignant } \\
\text { cells. Lacks proven } \\
\text { efficiency } \\
\text { Live birth and ongoing } \\
\text { pregnancy rates of } \\
37.7 \%\end{array}$} \\
\hline & $\begin{array}{l}\text { Surgical removal of tissue } \\
\text { preserved for later } \\
\text { transplantation in } \\
\text { adulthood }\end{array}$ & $\begin{array}{l}\text { Who do not have } \\
\text { sufficient time for } \\
\text { ovarian } \\
\text { stimulation }\end{array}$ & $\begin{array}{l}\text { No delay in initiation of } \\
\text { cancer treatment. Does not } \\
\text { require ovarian stimulation } \\
\text { Eliminate need for sperm } \\
\text { donation }\end{array}$ & \\
\hline
\end{tabular}

See references: Anderson et al., ${ }^{2}$ Rodriguez-Wallberg and Oktay, ${ }^{3}$ Royal College of Nursing, ${ }^{4}$ American Society of Clinical Oncology. ${ }^{10}$

the topic is a significant barrier to nurse's willingness to undertake fertility discussions. ${ }^{35-39}$ Research reflective of nurse practices in the United States and Netherlands also indicates role confusion; while some nurses view fertility discussion as their responsibility, ${ }^{36,40}$ others believe it is outside their scope of practice. ${ }^{41}$ Alternatively, some nurses view it as a joint doctor/nurse role. ${ }^{35}$ Similarly, no clear consensus exists among oncologists regarding responsibility for discussion. ${ }^{42}$ International studies highlight that a patient's poor survival prognosis may negatively influence both nurses' and doctors' willingness to broach the subject. ${ }^{36,39,40,43-47}$

Given the international consensus indicating the imperative of retaining reproductive potential for TYAs following cancer and the negative effects of not doing so, it is important to further explore factors that influence nurses in undertaking fertility discussions. Research suggests that by virtue of their primary and extended contact, nurses are generally more available to patients than doctors, ${ }^{48}$ are in an optimal position to have FP discussions, ${ }^{38,41,49,50}$ and play a pivotal role in addressing fertility concerns. ${ }^{51}$ Consequently, a more comprehensive understanding from the nurse's perspective on this important topic is vital to better support TYAs with fertility concerns.

The aims of this study were to explore and interpret nurses' experiences, feelings, and associated meanings attached to undertaking fertility-related discussions with TYA cancer patients aged 13-24 years (United Kingdom definition for this patient population $)^{52}$ to advance understanding of factors that facilitate or hinder such discussions to progress clinical practice.

\section{Methods}

A qualitative interpretive phenomenological analysis (IPA) approach was used. ${ }^{53}$ IPA involves a dual interpretive process dedicated to the exploration of meaning; a "double hermeneutic" whereby the researcher is trying to make sense of the participant trying to make sense of their experiences. ${ }^{54}$ Ethical approval was granted by the local NHS Research Ethics Committee and University.

The study used a purposive sample of 11 nurses currently working on a Teenage Cancer Trust (TCT) Unit in England. Study details were distributed to all 34 nurses who fulfilled the inclusion criteria: any registered nurse employed on the TCT unit for a minimum of 6 months and who interacted with TYAs before initiation of cancer treatment. IPA utilizes small sample sizes that allow for depth of analysis and an idiographic focus on the "particular" uniquely embodied experience, rather than more general claims. ${ }^{53}$ Participation was voluntary, and written consent was obtained.

The interview schedule (Table 2) was constructed by E.W. Interviews were conducted by E.W. between February and 


\section{Table 2. Interview Schedule}

Can you tell me about your past experiences and the current process operating on the unit associated with fertility discussions?

What do you think of the current process?

Can you tell me how you feel about your present role in undertaking a fertility discussion?

Can you tell me what you think the issues are/might be in offering fertility preservation to all TYAs at risk for cancer related infertility?

What do you believe are the factors which may hinder or promote the likelihood of you discussing fertility issues with your patients?

What would you suggest are ways to overcome these barriers?

If you had to describe the greatest difficulty in discussing fertility issues with TYAs, what would you say?

Can you describe any possible factors which may increase the likelihood of you discussing fertility related issues?

How much do you know about local or national guidelines on cancer-related infertility?

How do you see your role in discussing fertility related issues with TYAs?

If this role was seen to be a nursing responsibility, how would you feel?

What preparation, if any, would you require to undertake this role?

May 2016. The interviews, ranging in length from 28 to 44 minutes, were digitally recorded and transcribed verbatim. Data were securely stored, and confidentiality and anonymity were assured by removing all identifiable information. ${ }^{55}$

Data analysis conformed to the IPA analytical process ${ }^{53}$ (Fig. 1). In accordance with Yardley's ${ }^{56}$ quality criteria, commitment and rigor were maintained by ongoing discussion of emerging codes between authors to test and develop the coherence and plausibility of the interpretation. Clarifications and modifications were made to increase the consistency of the analysis. Themes were elicited from the responses of over 50\% of participants, although the focus was primarily on meaning rather than frequency. ${ }^{53}$ The master table of themes (Table 3) allows for transparency of the validity of the interpretation based on the quotations. ${ }^{56}$

\section{Results}

The 11 participants ranged in age from 21 to over 50 years and reflected various levels of nursing experience and United Kingdom pay scale banding (Table 4, participant demographic data). Two inter-related super-ordinate themes were selected for discussion in this article based on their international relevance in supporting nurses to effectively manage fertility issues.

\section{Parents/family control}

Nurses experienced parents/family as self-appointed informal gatekeepers, who nurses perceived to control access to the TYA. This hindered them in speaking privately with the TYA about fertility.

\footnotetext{
" ...if they have got their parent there urm and their parent is very controlling... his family they weren't very helpful...I think I did ask for his family to leave the room for a minute while I spoke to him, but they were coming in and out still ... But I guess you have just got to ask them [TYA about fertility] haven't you." (P7).

"I don't know whether I would necessarily find it uncomfortable talking directly to a patient, but if they [TYA] were surrounded, a patient with family, I would find that quite challenging...I wanted to speak to them alone" (P6).
}

Seemingly, parents were viewed by nurses as "controlling" (defined as the power to influence or direct people's

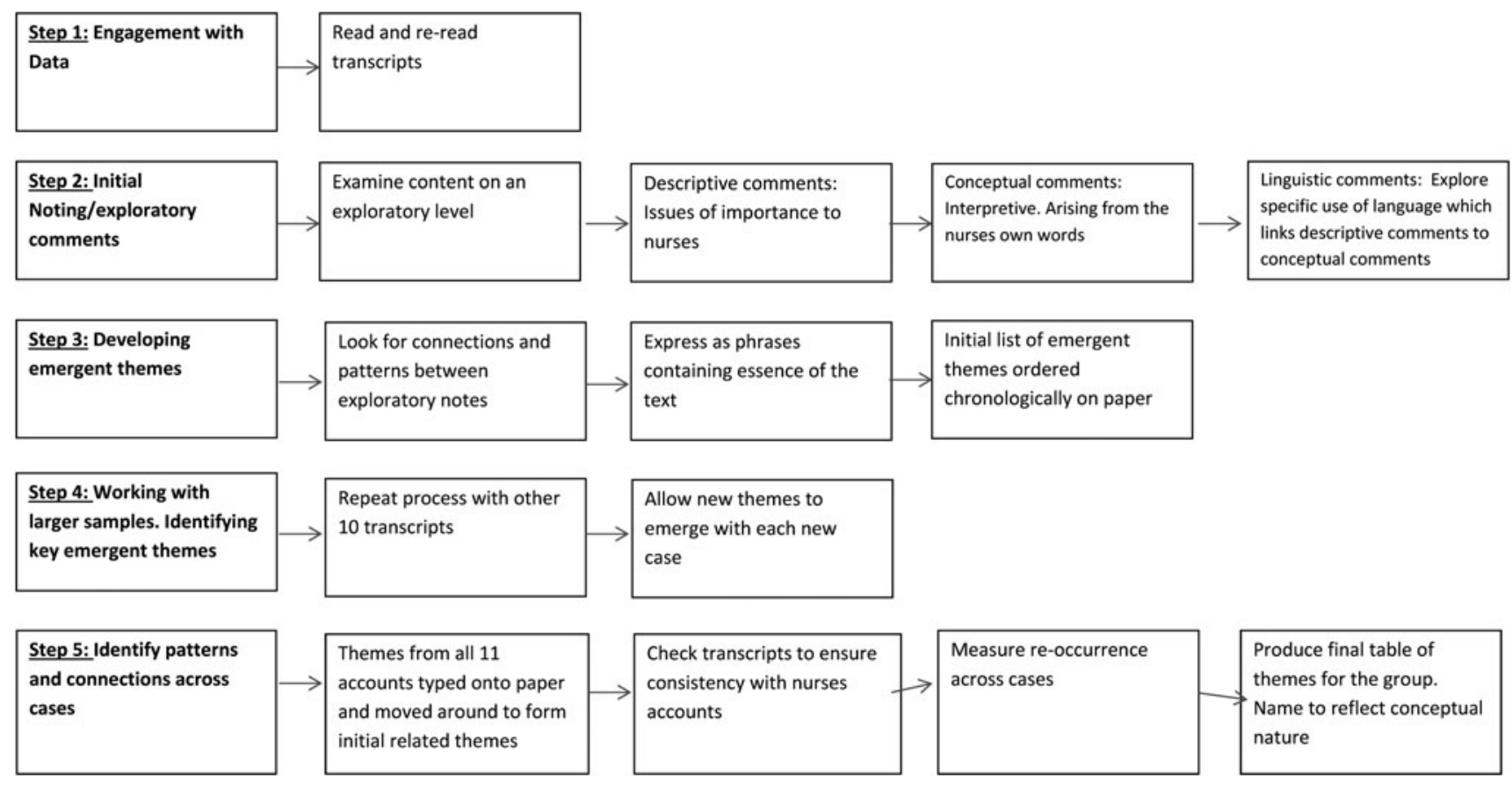

FIG. 1. Steps in the interpretive phenomenological analysis analytical process. ${ }^{53}$ 
Table 3. Master Table of Themes for All 11 Participants Illustrated with Sample Quotations

\begin{tabular}{|c|c|}
\hline Participant number & Quotations \\
\hline \multicolumn{2}{|l|}{ Parents/family control } \\
\hline 1 & $\begin{array}{l}\text { "I feel that they are more likely to say no if their mum is sat next to them, because they know what } \\
\text { they have to do. Whereas if they were on their own and you had that conversation, I don't know, I } \\
\text { feel like they would be more open to it." }\end{array}$ \\
\hline 1 & $\begin{array}{l}\text { "Because they were, he was very close to his parents and they didn't often leave him on his own in } \\
\text { the room, so it was a big thing to be able to say is there somewhere we can talk to him on his own } \\
\text { without you guys being there." }\end{array}$ \\
\hline 3 & $\begin{array}{l}\text { "I think sometimes parents try and hinder your conversations. They don't want to broach that } \\
\text { subject with children and sometimes feel we shouldn't as healthcare professionals." }\end{array}$ \\
\hline 4 & $\begin{array}{l}\text { "...to work with families, to work with them about explaining why we need to have that } \\
\text { conversation with young people urm and what we can do about it." }\end{array}$ \\
\hline 5 & $\begin{array}{l}\text { "I have had a parent that has said can we not talk about it urm, say with a } 13 \text { year old, we've had } \\
\text { that conversation before." }\end{array}$ \\
\hline 5 & $\begin{array}{l}\text { "With the young boys there is an embarrassment issue there as well of course, they are usually with } \\
\text { their parents and it's very difficult to get that conversation going with them." "We are trying to } \\
\text { explain to them, to the parents that it is a discussion, it's backed up with information." }\end{array}$ \\
\hline 6 & $\begin{array}{l}\text { "I don't know whether I would necessarily find it uncomfortable talking directly to patient, but if it } \\
\text { was surrounded, a patient with family would maybe find that quite challenging." "I think I would } \\
\text { feel I wanted to speak to them alone." }\end{array}$ \\
\hline 7 & $\begin{array}{l}\text { "Err no not his family, they weren't very helpful, they weren't really engaging with the } \\
\text { conversation... I think I did ask for his family to leave the room for a minute while I spoke to him } \\
\text { but they were coming in and out still. But I guess you have got to ask them haven't you. But then } \\
\text { asking them you have got to have them on their own to ask them." }\end{array}$ \\
\hline 7 & $\begin{array}{l}\text { "...It can't be your first sexual experience... I had to ask that whilst the commotion of his family } \\
\text { around." }\end{array}$ \\
\hline 7 & $\begin{array}{l}\text { "And their family urm because sometimes the families can be quite...they can quite, they can kind } \\
\text { of take front stage and let the urm, so getting through to the young person." }\end{array}$ \\
\hline 7 & $\begin{array}{l}\text { ". . but saying it privately when there is a lot of people around [family] was quite difficult. Trying } \\
\text { to talk about something privately without everyone else hearing, without all his family.", }\end{array}$ \\
\hline 9 & $\begin{array}{l}\text { "I am thinking of one situation where a parent had specifically told the consultant that they didn't } \\
\text { want him or us to talk to the child at all about fertility. And so we just didn't rightly or wrongly." }\end{array}$ \\
\hline 11 & $\begin{array}{l}\text { "But actually do you want to bring up such a conversation with perhaps again a young boys mum } \\
\text { sat next to him." }\end{array}$ \\
\hline \multicolumn{2}{|c|}{ Nurse as a continuing support role } \\
\hline 1 & $\begin{array}{l}\text { "And we have a very different relationship with them than the doctors do. So I think it would } \\
\text { almost come up more easily in conversation with us than it would with the doctors, if that makes } \\
\text { sense." }\end{array}$ \\
\hline 1 & "But I think it is, or should be part of our role to make sure that discussion has happened." \\
\hline 2 & $\begin{array}{l}\text { "It's the sort of thing that actually afterwards people do have questions you know, days, weeks, } \\
\text { months down the line about. And so inevitably it does fall under a nursing responsibility as well } \\
\text { urm." }\end{array}$ \\
\hline 3 & "Yeh Our job is to check...you pick up from that conversation and would carry it on.", \\
\hline 3 & "I would always check with the consultants that discussion had taken place." \\
\hline 4 & $\begin{array}{l}\text { "I think it's part of our job and we are working to support young people to make sure they have got } \\
\text { the right information.." }\end{array}$ \\
\hline 5 & $\begin{array}{l}\text { "...And if you have got rapport with them then they will start to open up with you and be able to } \\
\text { have those discussions." }\end{array}$ \\
\hline 6 & "An important part of my role is to ensure that it's been offered and spoken to them about." \\
\hline 6 & $\begin{array}{l}\text { "It's a continuing process. I think because like say they may have had the initial conversation but } \\
\text { quite often they are under our care when those appointments happen." }\end{array}$ \\
\hline 7 & "Urm I see my role more like in just making sure that they know the right choices." \\
\hline 8 & "So different people build up different relationships with young people." \\
\hline 9 & $\begin{array}{l}\text { "If you get to know them better and you have built a rapport with them it's a lot easier for them to } \\
\text { talk to you and for you to approach it with them." }\end{array}$ \\
\hline 10 & $\begin{array}{l}\text { "I think currently it is our role as well, or part of our role because once they have done that } \\
\text { discussion the patient or family might have more questions and we are the one who will be } \\
\text { dealing with them day to day." }\end{array}$ \\
\hline
\end{tabular}


Table 4. Participant Demographic Data

\begin{tabular}{|c|c|c|c|c|c|c|c|}
\hline Participant & Age & $\begin{array}{l}\text { United Kingdom } \\
\text { banding structure }\end{array}$ & Gender & $\begin{array}{c}\text { No. of } \\
\text { years as a } \\
\text { registered nurse }\end{array}$ & $\begin{array}{c}\text { No. of years } \\
\text { as a pediatric/TYA } \\
\text { cancer care nurse }\end{array}$ & $\begin{array}{c}\text { Specific } \\
\text { training } \\
\text { on fertility }\end{array}$ & $\begin{array}{l}\text { Specific } \\
\text { training } \\
\text { on TYAs }\end{array}$ \\
\hline 1 & $21-30$ & 5 & Female & 4.5 & 4.5 & Yes & Yes \\
\hline 2 & $21-30$ & 5 & Female & 4 & 4 & No & Yes \\
\hline 3 & $41-50$ & 6 & Female & 25 & 25 & No & No \\
\hline 4 & $41-50$ & 7 & Female & 21 & 21 & No & Yes \\
\hline 5 & $>50$ & 7 & Female & 29 & 20 & Yes & Yes \\
\hline 6 & $31-40$ & 6 & Female & 8 & 8 & No & Yes \\
\hline 7 & $21-30$ & 6 & Female & 6.5 & 6 & No & Yes \\
\hline 8 & $31-40$ & 6 & Female & 15 & 15 & No & Yes \\
\hline 9 & $>50$ & 7 & Female & 31 & 28 & No & Yes \\
\hline 10 & $31-40$ & 6 & Female & 8 & 8 & No & Yes \\
\hline 11 & $21-30$ & 5 & Female & 7 & 6 & No & Yes \\
\hline
\end{tabular}

${ }^{a}$ Band 5: Initial grade of qualified nurse. Band 6: Experienced senior nurse with more responsibility for the overall running of the ward. Band 7: Ward manager/ward sister responsible for the management of staff and has control of the ward budget. ${ }^{75}$

TYAs, teenagers and young adults.

behavior or the course of events). ${ }^{57}$ Nurses' sense of control appeared to be unwillingly relinquished to the family. This challenged nurses' determination to speak to the TYA about fertility issues while alone, which appeared to be an essential facilitator.

From an alternative viewpoint, the quotation below suggests that nurses feel that TYAs themselves may prefer to be alone when discussing sensitive issues such as fertility and sexual function.

\footnotetext{
"Whereas if they were on their own [TYA] and you had that conversation.... I feel like they would be more open to it" (P1)
}

Nurses experienced parents' constant physical presence as an obstacle to open communication, rather than anything they say or do.

\begin{abstract}
"...he was very close to his parents and they didn't often leave him on his own...so it was a big thing to be able to say is there somewhere we can talk to him on his own without you guys being there" (P1).
\end{abstract}

Here the nurse appears to try to make sense of her experience by her use of the expression "big thing," which appears to emphasize her perception of the enormity of the task of accommodating the distinctive needs and priorities of the TYA and those of parents. Re-establishment of personal control is viewed as a priority, and she perceives that this will be facilitated by the absence of parents. Participant seven experienced difficulty in "getting through to the young person" because "they [family] can kind of take front stage." The curious use of this idiom hints at her perception of viewing the family at the forefront of care; this appears to be contrary to her perception of the nursing ideal of patient-centered care.

The following account supports nurses' perceptions that parents' controlled access to the TYA:

"I have had a parent that has said can we not talk about it um, [fertility] say with a 13 year old..." (P5).

A subtle difference in language expression and meaning illustrated in the following nuanced account supports the belief and consequent action that it was unacceptable to speak to the young person:

"I am thinking of one situation where a parent had specifically told the consultant that they didn't want him or us to talk to the child [14 years] at all about fertility. And so, we didn't, rightly or wrongly" (P9).

These nurses present a passive acquiescence within a situation where the decision had been removed from them, with a relinquishing of personal agency connected to a perceived lack of control over events and the ability to influence them.

Further restrictions imposed by parental gatekeeping were experienced:

\footnotetext{
"Sometimes parents try and hinder your conversations... they don't want to broach that subject [fertility] with children and sometimes feel we shouldn't as healthcare professionals" (P3).
}

Parents of younger males expressed doubt that their son was capable or mature enough to engage in masturbation [required for semen storage], and several nurses reported an "embarrassment issue" on the young males' part to be a barrier to conversations, due to the intimate nature of the subject.

Discussion of sexually related issues was also a source of apprehension for nurses, compounded by the challenges of parents'/families' presence.

\footnotetext{
"It can't be your first sexual experience...I had to ask that whilst the "commotion' of his family around" (P7)
}

As a facilitating action to manage the triadic relationship, nurses placed emphasis on communicating with parents about the importance of FP discussion. This was seen as a way of mitigating parents'/families' capacity to exercise control over access to TYAs, to permit communication. Arguably, the nurses' ability to articulate the benefit of a discussion is seen as a controllable event, helping to reconcile opposing beliefs.

\footnotetext{
"... to work with families about explaining why we need to have that conversation with young people urm and what we can do about it" (P4).
} 


\begin{abstract}
"...trying to explain to them, to the parents that it is a discussion, it's backed up with information...they [young people] shouldn't be denied that opportunity" (P5).
\end{abstract}

\section{Nurse as a continuing support role}

Ten out of eleven nurses discussed their experiences and feelings associated with fertility discussions which revealed a sense of responsibility for such communication. Rather than being primarily responsible, nurses acknowledged that it was part of their role, but the emphasis was given to providing an ongoing supportive function. This appeared to provide nurses with a sense of purpose and self-worth and opportunity to fulfill what they perceived as a valuable role in responding to evolving queries.

\footnotetext{
"It's the sort of thing that actually afterwards people do have questions you know, days, weeks, months down the line about. And so it inevitably does fall under a nursing err responsibility as well", (P2).

"I think currently it is our role [discussing fertility] as well, or part of our role because once they [doctors] have done that discussion the patient or family might have more questions and we are the one who be dealing with them day to day" (P10).
}

The nurses' perception of the supportive nature of their role encompassed a "checking responsibility" to ensure that the doctors had undertaken the discussion. Several nurses attempted to understand their role in fertility care as an ongoing process rather than a "one off" discussion. Nurses described it as a "continuing process" to pick up from the doctor's initial conversation and "carry it on" in a supportive capacity.

\footnotetext{
"It's a continuing process... they [TYA] may have had the initial conversation but quite often they are under our care when those [FP] appointments happen" (P6).
}

The use of the phrase "may have had" hints at this nurse's uncertainty as to whether the discussion had definitely occurred and reinforces the nurses' perceived need for a checking responsibility.

There seems to be a sense here of the nurses' willingness to engage with TYAs and contribute in a useful way that was personally meaningful to them, providing ongoing support to TYAs along the continuum of their cancer journey.

The success of the continuing supportive role was often seen to be dependent on the nature of nurse-TYA relationship, and establishment of rapport was viewed as beneficial in facilitating this role. Interestingly, no nurses viewed their relationship with TYAs as a potential barrier; in fact, all perceived it to be a facilitator for open conversation.

\footnotetext{
"If you have got rapport with them [TYA], then they will start to open up with you and be able to have those discussions" (P5).
}

"If you get to know them better and you have built up a rapport with them it's a lot easier for them to talk to you and for you to approach it with them" (P9).

Here, a supportive relationship is seen to be potentially beneficial for both the nurse and the TYA.
Nurses also experienced very "different relationships" with TYAs to those held by doctors, which they perceived to be conducive in enabling the conversation to emerge naturally within day-to-day interactions. These beneficial relationships were perceived to facilitate the nurses' ongoing supportive role; notably, while not accepting responsibility for the initial discussion.

\section{Discussion}

In this study, an important finding was the significance of the perceived control held by parents/family that nurses experienced as self-appointed informal gatekeepers. Parents/family attempted to control fertility information and their wishes were often acceded to. Similarly, De Vries et al. ${ }^{58}$ investigated attitudes of physicians and parents toward discussing infertility risks with young males and also identified that parents were found to exert "strategic control" (p389) regarding their son's involvement in discussions due to concerns about their sexual immaturity. However, in contrast with the current study, 14/15 physicians in De Vries et al's ${ }^{58}$ study reported discussing the topic with TYAs, even if parents refused to give permission.

These contrasting findings may be explained by the sample composition of physicians rather than nurses. Previous research has identified that nurses feel less knowledgeable ${ }^{59,60}$ and less comfortable ${ }^{49}$ discussing fertility issues than physicians. Hence, nurses in the present study may have felt less confident in disregarding and overriding parent's wishes.

One possible explanation why parents may not allow TYAs to be approached may be attributed to their sole preoccupation with immediate survival, ${ }^{47}$ assumption that TYAs cannot comprehend the process, ${ }^{61,62}$ and parental/family concerns about further distressing the TYA who may be emotionally overwhelmed following a traumatic cancer diagnosis. $^{29,44,48}$ However, research has demonstrated that patient and parent discomfort/anxiety levels are often overestimated by health care professionals. ${ }^{30,63}$

TYAs desire to be active decision makers ${ }^{29-32}$ and can indeed cope with fertility matters being raised alongside a cancer diagnosis with support. ${ }^{64}$ While parental concerns are understandable, evidence suggests that parenthood priorities shift over time and become a significant concern into survivorship. ${ }^{14,30}$ Furthermore, cancer survivors diagnosed when aged 10-21 years often regretted that infertility was not discussed at the time of diagnosis. ${ }^{30}$

Nurses in this study experienced the necessity to negotiate what they perceived as the "challenges" of parental control. They reported the need "to work with families..." (p4) and to "try to explain to them..." (p5), as facilitating actions in an effort to emphasize the significance of a FP discussion to parents/families. Nurses saw this as a way of supporting TYA participatory decision-making. Balancing TYA engagement with parental involvement is pivotal, considering that parents and TYAs do not view oncofertility decision-making in the same way ${ }^{29}$ and may have discrepant priorities regarding future fertility intentions. ${ }^{65}$ If they desire, TYAs should participate in discussions, taking account of their emotional and mental maturity to freely voice their preferences. ${ }^{64,66}$

Paradoxically, even those TYAs who do not prioritize future parenthood value information regardless of their decision to proceed with FP or not. ${ }^{14,21,63,67}$ This suggests that further explanatory communication with parents about the 
value of a FP discussion, as advocated in this study, is indeed required to facilitate the TYAs' reproductive priorities to be voiced. Potential difficulties should be skillfully anticipated and managed by nurses. Further research is needed to explore ways of effectively engaging with parents to ensure that TYA views are considered, given the diversity of this patient population in terms of age and levels of autonomy, which may be factors influencing communication strategies.

In this study, nurses' perceptions of their role in fertility discussions were clearly expressed as forming part of a "continuing process" rather than a "one off" discussion, which supports the findings of previous United States research. ${ }^{36}$ In addition, nurses also acknowledged the need for a "checking responsibility" and expressed doubts whether the TYA "may have had" (P6) a discussion. These findings reinforce the need for clear role delineation; allocating nurse responsibility for establishing and maintaining links with fertility specialists may contribute to ensuring that TYAs' reproductive needs are met.

Research suggests that having access to a FP specialist $^{38,68,69}$ and close collaboration with the fertility team ${ }^{70,71}$ are important determinants in discussing FP. Therefore, while there is a need for a clearly defined role for nurses' in raising the issue of fertility routinely, ${ }^{51}$ all members of the multidisciplinary team are integral in providing oncofertility support, ${ }^{72,73}$ considering that fertility concerns may be present at any stage of the cancer trajectory. ${ }^{74}$

In the current study, nurses perceived the nature of their relationship with TYAs as "very different" to those experienced by doctors and a potential facilitator underpinning effective fertility communication and support. The establishment of rapport was seen to enhance such relationships. These findings highlight the importance of utilizing the benefits of the nurse-patient relationship if nurses are to be effective advocates for TYAs.

\section{Limitations}

While providing valuable data on this under-researched issue, the small self-selected homogenous sample, recruited from one specialist unit in England, limits generalization to a wider population. A self-selected sample may have resulted in participants with a greater interest in the fertility topic. In addition, TCT Units in England provide care for the 1324 year age range. ${ }^{52}$ Further research investigating the agespecific challenges relating to FP discussions within this age group is warranted, to expand upon our observations and inform TYA care providers of these patients' specific needs.

\section{Conclusion}

This study offers new insights into this significant contemporary issue from the perspective of nurses themselves. Biological parenthood may not be a priority for all TYAs. However, nurses are uniquely positioned to play a significant role in helping to fulfill hopes of parenthood after cancer for those TYAs who desire it and improve overall quality of life into survivorship.

\section{Acknowledgment}

The authors acknowledge the support and guidance provided by Martyn Geary during the study.

\section{Author Disclosure Statement}

No competing financial interests exist.

\section{Funding Information}

No funding was received for this article.

\section{References}

1. Cancer Research UK. Teenagers and young adult cancer statistics, England and Wales. London: Author; 2016. Accessed October 1, 2018 from: https/www.cancerresearch.org/cancerinfo/cancerstats/keyfacts/teenage-and-young-adult-cancer

2. Anderson A, Mitchell RT, Kelsey T, et al. Cancer treatment and gonadal function: experimental and established strategies for fertility preservation in children and young adults. Lancet Diabet Endocrinol. 2015;3(7):556-67.

3. Rodriguez-Wallberg KA, Oktay K. Fertility preservation during cancer treatment. Cancer Manag Res. 2014;6:105-17.

4. Royal College of Nursing. Fertility preservation: clinical professional resource. London: RCN; 2017. Accessed October 1, 2018 from: www.ren.orh.uk

5. British Fertility Society. A strategy for fertility services for survivors of childhood cancer. London: BFS; 2003. Accessed September 23, 2018 from: https//www.britishfertilitysociety .org.uk

6. National Institute for Health and Clinical Excellence. Fertility: assessment and treatment for people with fertility problems: people with cancer who wish to preserve fertility. London: NICE; 2013. Accessed September 1, 2018 from: www.nice .org.uk

7. Scottish Intercollegiate Guidelines Network. Long term follow-up of survivors of childhood cancer. London: SIGN; 2013. Accessed September 6, 2018. from: www.sign.ac.uk

8. German Society of Haematology and Medical Oncology. Onkopedia guidelines: adolescents and young adults (AYA) guideline Onkopedia Leitinien. Tubingen: DGHO; 2012. Accessed August 14, 2018 from: www.onkopedia-guidelines.info

9. Clinical Oncology Society of Australia. Fertility preservation for adolescents and young adults diagnosed with cancer: guidance for health professionals. Sydney: COSA; 2014. Accessed September 14, 2018: from: http/wiki .cancer:AYAcancer

10. American Society of Clinical Oncology. Clinical practice guideline update. Recommendations on fertility preservation in cancer patients. Virginia: ASCO; 2018. Accessed September 23, 2019 from: https//www.jco.ascopubs.org

11. Royal College of Physicians, Royal College of Radiologists, Royal College of Obstetricians and Gynaecologists. The effect of cancer treatment on reproductive function: guidance on management. Report of a working party. London: RCOP; 2007. Accessed September 23, 2018 from: www.rcr .ac.uk/files/publications

12. Ellis SJ, Wakefield CE, McLoone JK, et al. Fertility concerns among child and adolescent cancer survivors and their parents: a qualitative analysis. J Psychosoc Oncol. 2016;34(5):347-62.

13. Barlevy D, Wangmo T, Elger BS, Ravitsky V. Attitudes, beliefs and trends regarding adolescent onco-fertility discussions: a systematic literature review. J Adolesc Young Adult Oncol. 2016;5(2):19-34.

14. Taylor JF, Ott MA. Fertility preservation after a cancer diagnosis: a systematic review of adolescents, parents and providers perspectives, experiences and preferences. J Pediatr Adolesc Gynaecol. 2016;29(6):585-98. 
15. Despande NA, Braun IM, Meyer FL. Impact of fertility preservation counselling and treatment on psychological outcomes among women with cancer: a systematic review. Cancer. 2015;121(22):3938-47.

16. Finney E, Johnson EK. Challenges in fertility preservation among adolescent cancer survivors. Pediatr Blood Cancer. 2018;64:e27042.

17. Wilkes S, Coulson S, Crosland A, et al. Experience of fertility preservation among younger people diagnosed with cancer. Hum Fertil. 2010;13(3):151-8.

18. Srikanthan A, Ethier J, Eitan A, et al. The voices of young women with breast cancer: providing support and information for improved fertility preservation discussions. J Adolesc Young Adult Oncol. 2019;8(5):547-53.

19. Ussher JM, Parton C, Perz P. Need for information, honesty and respect: patient perspectives on health care professionals' communication about cancer. Reprod Health. 2018;15(2):1-12.

20. Logan S, Perz J, Ussher JM, et al. A systematic review of patient onco-fertilty support needs in reproductive cancer patients aged 14-45 years of age. Psychooncology. 2017; 27:401-9.

21. Fink DM, Sheeder J, Laxmi A, et al. A review of the oncology patients challenges for utilizing fertility preservation services. J Adolesc Young Adult Oncol. 2017;6(1):31-44.

22. Mancini J, Dominique R, Preau M, et al. Infertility induced by cancer treatment: inappropriate or no information provided to majority of French survivors of cancer. Fertil Steril. 2007;90:1616-25.

23. Corney RH, Swinglehurst AJ. Young childless women with breast cancer in the UK: a qualitative study of their fertilityrelated experiences, options, and the information given by health professionals. Psychooncolgy. 2014;23:20-6.

24. Peddie VL, Porter MA, Barbour R, et al. Factors affecting decision making about fertility preservation after cancer diagnosis: a qualitative study. BJOG. 2012;119(9):1049-57.

25. Peate M, Meiser B, Hickey M, et al. The fertility-related concerns, needs and preferences of younger women with breast cancer: a systematic review. Breast Cancer Res Treat. 2009;116:215-23.

26. Armuand GM, Wettergren L, Rodriguez-Wallberg KA, et al. Women more vulnerable than men when facing risk for treatment-induced infertility: a qualitative study of young adults newly diagnosed with cancer. Acta Oncol. 2015;54:243-52.

27. Lee RJ, Wakefield A, Foy S, et al. Facilitating reproductive choices: the impact of health services on the experiences of young women with breast cancer. Psychooncology. 2011; 20(10):1077-52.

28. Garvelink M, Kuile MM, Fischer MJ, et al. Development of a decision aid about fertility preservation for women with breast cancer in the Netherlands. J Psychosom Obstet Gynaecol. 2013;34:170-8.

29. Barlevy D, Wangmo T, Ash S, et al. Oncofertilty decision making: findings from Israeli adolescents and parents. J Adolesc Young Adult Oncol. 2019;8 (1):1-10.

30. Stein DM, Victorson DE, Choy T, et al. Fertility preservation preferences and perspectives among adult male survivors of paediatric cancer and their parents. J Adolesc Young Adult Oncol. 2014;3(2):75-82.

31. Quinn GP, Murphy D, Knapp C, et al. Who decides? Decision making and fertility preservation in teens with cancer: a review of the literature. 2011;49:337-46.

32. Wright CJ, Coad J, Morgan S, et al. 'Just in case': the fertility information needs of teenagers and young adults with cancer. Eur J Cancer Care. 2014;23(2):189-98.
33. Chan J, Letourneau J, Salem W, et al. Regret around fertility choices is decreased with pre-treatment counselling in gynaecologic cancer patients. J Cancer Surviv. 2017;11(1): $58-63$.

34. Letourneau JM, Ebbel E, Katz P, et al. Pre-treatment fertility counselling and fertility preservation improve quality of life in reproductive age women with cancer. Cancer. 2012;118:1710-17.

35. Reebals JF, Brown R, Bucker EB. Nurse practice issues regarding sperm banking in adolescent male cancer patients. J Pediatr Oncol Nurs. 2006;23(4):182-88.

36. King L, Quinn GP, Vadaparampil ST, et al. Oncology nurses' perceptions of barriers to discussion of fertility preservation with patients with cancer. Clin J Oncol Nurs. 2008;12(3): 467-76.

37. Nagel K, Neal M. Discussions regarding sperm banking with adolescent and young adult males who have cancer. J Pediatr Nurs. 2008;25(2):102-6.

38. Krouwel EM, Nicolai MP, Van Steijn-van Tol AQ, et al. Fertility preservation counselling in Dutch oncology practice: are nurses ready to assist physicians? Eur J Cancer Care. 2016;26:e12614, 1-11.

39. Vadaparampil ST, Clayton H, Quinn GP, et al. Pediatric oncology nurses attitudes related to discussing fertility preservation with pediatric patients and their families. J Pediatr Oncol Nurs. 2007;24(5):255-63.

40. Clayton H, Quinn G, Lee J, et al. Trends in clinical practice and nurses attitudes about fertility preservation for paediatric patients with cancer. Oncol Nurs Forum. 2008;35(2):249-55.

41. Keim-Malpass J, Fitzhugh H, Smith LP, et al. What is the role of the oncology nurse in fertility preservation counselling and education for young patients? J Cancer Educ. 33(6):1301-1305.

42. Tennyson R, Griffiths HC. A systematic review of professionals experiences of discussing fertility issues with adolescents and young adults with cancer. J Adolesc Young Adult Oncol. 2019;8(4):387-97.

43. Ussher JM, Cummings J, Dryden A, et al. Talking about fertility in the context of cancer: healthcare professional perspectives. Eur J Cancer Care. 2016;25(1):99-111.

44. Armuand GM, Nilsson J, Rodriguez-Wallberg KA. Physicians self-reported practice behaviour regarding fertility related discussions in paediatric oncology in Sweden. Psychooncology. 2017;26:1684-90.

45. Buske D, Sender A, Richter D, et al. Patient-physician communication and knowledge regarding fertility issues from German oncologists. J Cancer Educ. 2016;31(1): 115-22.

46. Quinn G, Vadaparmpil ST, King L, et al. Impact of physicians personal discomfort and patient prognosis on discussion of fertility preservation with young cancer patients. Patient Educ Couns. 2009;77:338-43.

47. Vindrola-Padros C, Dyer KE, Cyrus J, Lubker M. Healthcare professional's views on discussing fertility preservation with young cancer patients: a mixed method systematic review of the literature. Psychooncology. 2017;26:4-14.

48. Murray AN, Chrisler JC, Robbins ML. Adolescents and young adults with cancer: oncology nurses report attitudes and barriers to discussing fertility preservation. J Oncol Nurs. 2016;20(4):E93-9.

49. Fuch A, Kashanian JA, Clayman ML, et al. Paediatric oncology provider's attitudes and practice patterns regarding fertility preservation in adolescent male cancer patients. J Pediatr Haemotol Oncol. 2016;38(2):118-22. 
50. Quinn GP, Vadaparampil ST, Gwede CK, et al. Discussion of fertility preservation with newly diagnosed patients: oncologists views. J Cancer Surviv. 2007;1:146-55.

51. Gorman JR, Usita P, Madlensky L, Peirce J. Young breast cancer survivors: their perspectives on treatment decisions and fertility concerns. Cancer Nurs. 2011;34(1):32-40.

52. Teenage Cancer Trust. Cancer Units London: TCT; 2018. Accessed April 2, 2019 from: https www.teenagecancertrust .org/what-we-do/specialist-services/units

53. Smith JA, Flowers P, Larkin M. Interpretive phenomenological analysis: theory, method and research. London: Sage Publications; 2009.

54. Smith JA, Osborn M. Interpretive phenomenological analysis. In: Smith JA (Eds). Qualitative psychology: a practical guide to research methods. London: Sage Publications; 2018; pp. 25-52.

55. UK Public General Acts. Data protection act. London: Author; 2018. Accessed October 31, 2019 from: www.legislation.gov .uk/ukpga/1998/29/content

56. Yardley L. Demonstrating validity in qualitative psychology. In: Smith JA (Eds). Qualitative psychology: a practical guide to research methods. London: Sage Publications; 2018; pp. 257-72.

57. Macmillan dictionary. London: Pan Macmillan; 2018. Accessed August 12, 2018 from: www.macmillandictionaries .com

58. De Vries MC, Bresters D, Engberts DP, et al. Attitudes of physicians and parents towards discussing infertility risks and semen cryopreservation with male adolescents diagnosed with cancer. Paediatr Blood Cancer. 2009;53:386-91.

59. Kurt SK, Topcu I, Savaser S, et al. Knowledge and practices of doctors and nurses in oncology clinics regarding sperm bank use in adolescent boys diagnosed with cancer. J Current Paed. 2013;11(3):114-20.

60. King JW, Davies MC, Roche N, et al. Fertility preservation in women undergoing treatment for breast cancer in the UK: a questionnaire study. Oncologist. 2012;17:910-16.

61. Knapp CA, Quinn GP, Rapalo D, Woodsworth L. Patientprovider communication and reproductive health. In: Quinn GP, Vadaparampil ST (Eds). Reproductive health and cancer in adolescents and young adults. New York: Springer; 2012; pp. 175-86.

62. Yee S, Fuller-Thomson E, Lau A, Greenblatt EM. Fertility preservation among Ontario oncologists. J Cancer Educ. 2012;27:362-68.

63. Ginsberg JP, Ogle SK, Tuchman LK, et al. Sperm banking for adolescent and young adult cancer patients: sperm quality, patient and parent perspectives. Pediatr Blood Cancer. 2008; 50:594-8.

64. Crawshaw MA, Glaser AW, Hale JP, Sloper P. Male and female experiences of having fertility matters raised along- side a cancer diagnosis during the teenage and young adult years. Eur J Cancer Care. 2008;18:381-90.

65. Klosky LK, Simmons JL, Russel KM, et al. Fertility as a priority among at-risk adolescent males newly diagnosed with cancer and their parents. Support Cancer Care. 2015; 23:333-41.

66. Sisk BA, Canavera K, Sharma A, Baker JN, Hohnson L. Ethical Issues in the care of adolescent and young adult oncology patients. Pediatr Blood Cancer. 2018;66(5):e27608.

67. Wyns C, Collienne C, Shenfield F, Robert A, et al. Fertility preservation in the male paediatric population: factors influencing the decision of parents and children. Hum Reprod. 2015;30(9):2022-30.

68. Loren AW, Brazauskas R, Chow EJ, et al. Physician perception and practice patterns regarding fertility preservation in hematopoietic cell transplant recipients. Bone Marrow Transplant. 2013;48:1091-97.

69. Louwe LA, KuileT, Hilders M, et al. Oncologists practice regarding fertility preservation in female cancer patients: a pilot study in the Netherlands. J Psychosom Obstet Gynecol. 2013;34:129-32.

70. Goodman LR, Balthazar UL, Kim J, Mersereau JE. Trends of socioeconomic disparities in referral patterns for fertility preservation consultation. Hum Reprod. 2012;27(7):2076-81.

71. Vadaparampil ST, Quinn GP. Improving communication between oncologists and reproductive specialists to promote timely referral of patients with cancer. J Oncol Pract. 2013;9(6):300-2.

72. Stern CJ, Agresta F. Setting up a fertility preservation programme. Clin Obstet Gynecol. 2019;55:67-68.

73. Gorman JR, Bailey S, Pierce S, et al. How do you feel about fertility and parenthood? The voices of young female cancer survivors. J Cancer Surviv. 2012;6(2):200-9.

74. Crawshaw C. Psychological oncofertilty issues faced by adolescents and young adults over their lifetime: a review of the research. Hum Fertil. 2013;16(1):59-63.

75. National Health Service Confederation. National Health Service Employers: pay, roles, pensions and reward (table 5 appendix reference). London: NHS; 2019. Accessed September, 6, 2019 from: www.nhsemployers.org

Address correspondence to:

Wendy Norton, PhD, MSc

The Leicester School of Nursing and Midwifery

De Montfort University

Edith Murphy 8.17

Leicester LE1 9BH

United Kingdom

Email: wnorton@dmu.ac.uk 